\title{
Distributions of Dissolved Trace Metals in Surface Waters of Baffin Bay in the Canadian Arctic
}

TIA K. ANDERLINI ${ }^{1}$, JEAN-ÉRIC TREMBLAY ${ }^{2}$, AND JAY T. CULLEN ${ }^{1}$

${ }^{1}$ School of Earth and Ocean Sciences, University of Victoria, Victoria, BC V8P 5C2, Canada (*correspondence tanderlini@uvic.ca and jcullen@uvic.ca)

${ }^{2}$ Département de Biologie, Université Laval, Quebec, QC G1V 0A6, Canada

This study investigates the distributions of essential micro and macronutrients in surface waters $(<500 \mathrm{~m})$ of Baffin Bay during summer 2019. Transects across major inlets and outlets of the Bay, including Davis and Nares straits and Jones and Lancaster sounds, are presented. A dissolved iron (DFe)- , and dissolved manganese (DMn)- rich, but macronutrient deplete, influx along the eastern side of Baffin Bay, is associated with the northward flow of relatively warm and saline Western Greenland Current (WGC) waters. The WGC may be enriched in DFe and DMn due to contact with shelf sediments and delivery of crustal material related to glacial wasting. Conversely, Baffin Island Current waters flowing North to South along the western side are less enriched in these metals but higher in macronutrient concentrations owing to the nutrient-rich Pacific component of Arctic Water entering Baffin Bay from the Canadian Arctic Achipelago. Dissolved bioactive elements like cadmium (DCd), copper (DCu), nickel (DNi) and zinc (DZn) are more concentrated in the Pacific component of Arctic Water. These metals have higher concentrations in the north and east of Baffin Bay proximate to inflows of Arctic Water at Lancaster and Jones sounds and Nares Strait. For instance, up to a 2.8-fold increase in these comparatively higher-mass metals can be seen in Pacificsourced Arctic Water, with average concentrations of 0.42 and $2.13 \mathrm{nM}$ observed at the mouth of Lancaster Sound for DCd and DZn, respectively. On the other hand, the average respective metal concentrations in WGC waters are 0.15 and $0.84 \mathrm{nM}$, indicating a lack of transport from the north. Meanwhile, average WGC DFe has up to a 6.8 -fold increase over the most northern waters within the bay, with WGC DMn similarly seeing over a 2 -fold increase. The interplay between biogeochemical and physical processes on the resulting spatial distributions of trace elements and dominant source and sink terms are discussed. 